\title{
Morphemes in Tips_-Taking Elementary Chinese Textbooks in Japan as a Subject ${ }^{*}$
}

\author{
GE Jing, YIN Ling-wei \\ North China University of Technology, Beijing, China
}

\begin{abstract}
Vocabulary acquisition is a foundation of second language acquisition. How to memorize vocabulary effectively is a troubling issue both for learners and teachers. The experiments show that the more closely connected between pair words, the higher rate of recurrence with correctness. Focusing on the connection of morphemes in Chinese vocabulary teaching can accelerate students' memories of new words. The author believes morpheme teaching is also evidently effective for those Chinese learners using Chinese characters in Japan. However, after examining the order of words with same morphemes in 14 elementary Chinese textbooks, the authors found that current textbooks have not provided a list of words with same morpheme thus imposing learners' memory burden due to learning repetitive words. Meanwhile, this paper proposes "radial networks" among morphemes with same words, also promotes the expansion of vocabulary by morpheme association.
\end{abstract}

Keywords: Chinese textbooks, Japan, radial network, vocabulary morpheme

\section{Introduction}

HE bao-yuan, ZHANG Hou-can, and CHEN Shu-yong (1983) noted that "in the case of roughly same amount of memory materials, people can memorize best for the interrelated-meaning words, meaningless words are the worst”.

ZHOU Guo-guang (2004) made a list for 24 closely-connected pair words in a random order. Then ZHOU demanded participants to recall these words. The experiment result shows that the closer connection between pair words, the higher rate of recurrence with correctness. After recalling the initial words without any order, all the words appear in the form of associated pairs. XU Cai-hua (2002) studied on the arrangement of vocabulary based on cognitive psychology in Chinese textbooks. She believed that morphemes with monosyllables should be listed in new words which can be conducive to the development of learners' "psychological dictionary".

In the process of second language acquisition, vocabulary is an essential part. In order to memorize words for learners quickly, how to effectively present these words is a vital issue for foreign language teachers. However, there are comparatively a few study papers on vocabulary teaching and grammar in current research. ZHANG Wang-xi (2000) pointed out that only 21 papers on vocabulary and vocabulary teaching, accounting for $11 \%$, exist among all the 211 selected papers. ZHANG He-sheng (2005) discovered that only 104 papers study on Chinese vocabulary, and 355 papers study on Chinese grammar from 1979 to 1999; only 14 papers on

\footnotetext{
* This paper is funded by “North China University of Technology Cultivation for Outstanding Young Teachers Program”: study on the Chinese teaching as a second language in China, Japan, English-speaking countries, and Germany.

GE Jing, lecturer, Ph.D., College of Humanities and Law, North China University of Technology.

YIN Ling-wei, lecturer, master, College of Humanities and Law, North China University of Technology.
} 
vocabulary and vocabulary teaching, accounting for 5\%, exist among 279 papers on Chinese teaching as second language. Putting the words with same morphemes as a set can allow learners to study morphemes from the initial core morphemes, then extend to the lexical scope, thus learners could remember a large number of words.

This paper examines the arrangement order of new words from 14 elementary Chinese textbooks published in Japan (see Table 1) and focuses on the appearance of morphemes to discuss the importance of morphemes in the elementary level of Chinese vocabulary teaching.

Table 1

Textbook List

\begin{tabular}{|c|c|c|c|c|}
\hline No. & Textbooks & Publish company & Author & Publish time \\
\hline 1 & To the Chinese & Asahi Press & Yang Kairong, Zhang Liqun & $2008 / 1$ \\
\hline 2 & Kumi Shanghai Trip & Surugadai Press & KURAMOI Takafumi, OHZAWA Riko & $2008 / 4$ \\
\hline 3 & Chinese College & Ikubundo Press & TAKENOBU Akira & $2008 / 4$ \\
\hline 4 & Chinese Time & Asahi Press & OHMORI Shinri & $2007 / 4$ \\
\hline 5 & Campus Life in Chinese & Asahi Press & Zhang shiying, Shen Lihua & $2007 / 4$ \\
\hline 6 & Open the door! Chinese & Asahi Press & KOIKE Ichiro, NAWA Naosuke & $2008 / 1$ \\
\hline 7 & $\begin{array}{l}\text { Instantly use Chinese- } \\
\text { Unforgettable Times }\end{array}$ & Ikubundo Press & Yang Guangjun, Zhang Ping, WATANABE Shuji & $2006 / 4$ \\
\hline 8 & Progress Everyday & Hakuteisha Press & SATO Haruhiko & $2007 / 4$ \\
\hline 9 & $\begin{array}{l}\text { Happy Chinese-Tomoko's } \\
\text { Beijing Study Life }\end{array}$ & Ikubundo Press & UENO Eiji & 2006/11 \\
\hline 10 & Approach to Chinese & Asahi Press & Yang Kairong, Zhang Liqun & $2006 / 4 / 1$ \\
\hline 11 & Challenge Chinese & Ikubundo Press & SAIJO Masaru, TANIGAWA Eiko, NISHII Katsuya & $2006 / 4$ \\
\hline 12 & Listening Chinese & Asahi Press & Yang Kairong, Zhang Liqun & $2007 / 1$ \\
\hline 13 & Question and Answer for Chinese & Asahi Press & Zhu Jizheng & $2006 / 4$ \\
\hline 14 & $\begin{array}{l}\text { Chinese Daily Reading and } \\
\text { Dialogues }\end{array}$ & Asahi Press & Fan Jianming, Shen Lihua, Zhang Shiying & $2006 / 4$ \\
\hline
\end{tabular}

\section{The Arrangement of New Words in Textbooks}

This paper is designed to examine occurrence of words in elementary textbooks. In order to study arrangement order of words with same morphemes in 14 textbooks, the paper gives the list of words with core morphemes (see Table 2).

Table 2

Morpheme and the Location of Occurrence in Textbook

\begin{tabular}{|c|c|c|c|}
\hline No. & Textbook & Morpheme & Occurrence in which lesson \\
\hline 1 & To the Chinese & $\begin{array}{l}\text { 本BEN、电DIAN、放FANG、 } \\
\text { 好HAO、面MIAN、天TIAN、 } \\
\text { 日RI、上SHANG }\end{array}$ & $\begin{array}{l}\text { 本 : 本BEN(notebook)3 本子BENzi(notebook)9 } \\
\text { 电 : 电视DIANshi(television)1 电影DIANying(movie)8 } \\
\text { 放 : 放假FANGjia(having vacation)16 放暑假 } \\
\text { FANGshujia(having summer vacation)13 } \\
\text { 好 :好HAO7 好吃HAOchi(delicious)5 好喝HAOhe(tastful)4 好 } \\
\text { 天HAOtian (sunny day)15 } \\
\text { 面 : 炒面chaoMIAN(fried noodles)9 方便面 } \\
\text { fangbianMIAN(instant noodles)10 } \\
\text { 天 : 每天meiTIAN(everyday)6 明天mingTIAN(tormorrow)3 } \\
\text { 上: 上SHANG(last;upper)3 上个月SHANGgeyue(last month)6 } \\
\text { 上课SHANGke(having class)9 }\end{array}$ \\
\hline
\end{tabular}


(Table 2 continued)

\begin{tabular}{|c|c|c|c|}
\hline No. & Textbook & Morpheme & Occurrence in which lesson \\
\hline 2 & Kumi Shanghai Trip & $\begin{array}{l}\text { 车CHE、电DIAN、开KAI、 } \\
\text { 商SHANG、信XIN }\end{array}$ & $\begin{array}{l}\text { 车 : 车站CHEzhan(station)5 车票CHEpiao(tickets)10 火车 } \\
\text { huoCHE(train)10 车里CHEli(in the car)13 电车 } \\
\text { dianCHE(tram)14 火车站huoCHEzhan(railway station)15 } \\
\text { 电 : 电视机DIANshiji(television)3 电脑室DIANnaoshi(computer } \\
\text { room)7 电梯DIANti(elevator)7 电车DIANche(tram)14 } \\
\text { 开 : 开始KAIshi(begin)3 开心KAIxin(delight)5 开通 } \\
\text { KAItong(open v.)7 开车KAIche(drive a car)8 } \\
\text { 商 : 商店SHANGdian(store)12 商场SHANGchang(shopping } \\
\text { mall)14 } \\
\text { 信 : 信XIN(credit)5 信用卡XINyongka(credit card)6 信用卡公 } \\
\text { 司XINyongka(credit card company)14 信箋 } \\
\text { XINjian(letterhead)11 }\end{array}$ \\
\hline 3 & Chinese College & $\begin{array}{l}\text { 北BEI、比BI、车CHE、抽 } \\
\text { CHOU、电DIAN、关GUAN、 } \\
\text { 回HUI、开KAI、老LAO、买 } \\
\text { MAI、卖MAI、女NV、起QI、 } \\
\text { 请QING、上SHANG、手 } \\
\text { SHOU、小XIAO、游YOU、 } \\
\text { 做ZUO }\end{array}$ & $\begin{array}{l}\text { 北 : 北边儿BEIbianr(north)4 北方人BEIfangren(northern } \\
\text { people)8 } \\
\text { 比 : 比BI(compare)10 比较BIjiao(compare)8 比赛 } \\
\text { BIsai(competition)7 } \\
\text { 车 : 车CHE(vehicles)17 车站CHEzhan(station)5 } \\
\text { 抽 : 抽血CHOUxue(draw blood)18 抽烟CHOUyan(smoke)9 } \\
\text { 电 : 电车DIANche(tram)5 电脑DIANnao(computer)9 电视 } \\
\text { DIANshi(television)20 电梯DIANti(elevator)19 电影 } \\
\text { DIANying(movie)7 } \\
\text { 关 : 关GUAN(close)16 关门GUANmen(shut the door)13 } \\
\text { 回 : 回国HUIguo(return home country)11 回家HUIjia(return } \\
\text { home)5 回来HUIlai(come back)13 回来见HUIlaijian(come back } \\
\text { and see)17 回去HUIqu(go back)11 } \\
\text { 开 : 开KAI(open)19 开会KAIhui(have a meeting)15 开水 } \\
\text { KAIshui(boiled water)9 开演KAIyan(perform begins)7 } \\
\text { 老 : 老家LAOjia(hometown)14 老婆LAOpo(wife)19 老师 } \\
\text { LAOshi(teacher)3 老斧LAOye(lord)15 } \\
\text { 买 : 买MAI(buy)4 买卖MAImai(trading)10 } \\
\text { 女 : 女生NVsheng(female students)9 女朋友 } \\
\text { NVpengyou(girlfriend)12 } \\
\text { 起 : 起QI(stand)12 起床QIchuang(get up)7 起来QIlai(stand } \\
\text { up)13 } \\
\text { 请 : 请QING(please)16 请多关照QINGduoguanzhao()3 请客 } \\
\text { QINGke(invite guests)6 } \\
\text { 上 : 上SHANG(upper)13 上课SHANGke(having class)10 上来 } \\
\text { SHANGlai(come up)13 上去SHANGqu(go up)13 上网 } \\
\text { SHANGwang(surf the internet)15 上学SHANGxue(go to } \\
\text { school)5 } \\
\text { 手 : 手SHOU(hand)13 手表SHOUbiao(watch)3 手机 } \\
\text { SHOUji(mobile phone)9 } \\
\text { 小 : 小狗XIAOgou(puppy)12 小时XIAOshi(hour)7 小说 } \\
\text { XIAOshuo(novel)5 小心XIAOxin(be careful)9 小熊猫 } \\
\text { XIAOxiongmao(little panda)19 小组XIAOzu(small group)17 } \\
\text { 游 : 游YOU(swim)14 游泳YOUyong(swim)8 } \\
\text { 做 : 做菜ZUOcai(cook dishes)12 做饭ZUOfan(cooking)8 }\end{array}$ \\
\hline
\end{tabular}


(Table 2 continued)

\begin{tabular}{|c|c|c|c|}
\hline No. & Textbook & Morpheme & Occurrence in which lesson \\
\hline 4 & Chinese Time & $\begin{array}{l}\text { 背BEI、车CHE、 } \\
\text { 大DA、电DIAN、 } \\
\text { 发FA、讲JIANG、 } \\
\text { 录LU、书SHU、 } \\
\text { 听TING、小 } \\
\text { XIAO、眼YAN }\end{array}$ & $\begin{array}{l}\text { 背: 背BEI(memorize)10 背诵BEIsong(memorize)9 } \\
\text { 车 : 车票CHEpiao(tickets)12 车站CHEzhan(station)7 } \\
\text { 大 : 大DA(general, major; big)2 大概DAgai(around, rough)14 大街DAjie(street)4 大 } \\
\text { 款DAkuan(wealthy person)11 大熊猫DAxiongmao(panda)4 大学DAxue(university)2 } \\
\text { 大衣DAyi(coat)10 大约DAyue(approximately)7 } \\
\text { 电 : 电车DIANche(tram)7 电话DIANhua(telephone)5 电脑DIANnao(computer)2 电 } \\
\text { 视DIANshi(television)2 电子词典DIANzicidian(electrical dictionary)9 电子琴 } \\
\text { DIANziqin(electrical keyboard)10 } \\
\text { 发 : 发FA(issue; send)5 发表FAbiao(publish)15 发言FAyan(make a speech)15 发音 } \\
\text { FAyin(pronunciation)2 } \\
\text { 讲 : 讲课JIANGke(give a lecture)13 讲台JIANGtai(platform)14 } \\
\text { 录 : 录像LUxiang(video recording)13 录音磁带LUyincidai(tape)12 录音机 } \\
\text { LUyinji(recorder)14 } \\
\text { 书 : 书SHU(book)2 书包SHUbao(schoolbag)2 书店SHUdian(bookstore)3 } \\
\text { 听 : 听TING(listen)2 听力TINGli(listening)12 听说TINGshuo(heard of)7 } \\
\text { 小 : 小XIAO(small)2 小姐XIAOjie(miss) } 8 \text { 小笼包XIAOlongbao(steamed bun)11 小 } \\
\text { 小卖店XIAOmaidian(grocery stores)4 小时XIAOshi(hour)6 小说XIAOshuo(novel)5 } \\
\text { 小提琴XIAOtiqin(violin)9 } \\
\text { 眼 : 眼睛YANjing(eyes)13 眼泪YANlei(tears)16 }\end{array}$ \\
\hline 5 & $\begin{array}{l}\text { Campus Life } \\
\text { in Chinese }\end{array}$ & $\begin{array}{l}\text { 打A、电DIAN、 } \\
\text { 教JIAO、酒JIU、 } \\
\text { 日RI、上SHANG、 }\end{array}$ & $\begin{array}{l}\text { 打 : 打DA9 打球DAqiu(play the ball)7 } \\
\text { 电: 电视DIANshi(television)12 电话DIANhua(telephone)13 电脑 } \\
\text { DIANnao(computer)14 } \\
\text { 教 : 教JIAO2 教材JIAOcai(textbook)3 教室JIAOshi(classroom)5 教书 } \\
\text { JIAOshu(teaching)10 } \\
\text { 酒 : 啤酒piJIU7 葡萄酒putaoJIU(wine)9 } \\
\text { 日 : 日本人RIbenren(Japanese)1 日元RIyuan(Japanese Yen)5 } \\
\text { 上 : 上SHANG13 上网SHANGwang(surf the Internet)11 }\end{array}$ \\
\hline 6 & $\begin{array}{l}\text { Open the } \\
\text { door! Chinese }\end{array}$ & $\begin{array}{l}\text { 爱AI、北BEI、车 } \\
\text { CHE、出CHU、 } \\
\text { 打A、大DA、 } \\
\text { 电DIAN、多 } \\
\text { DUO、法FA、可 } \\
\text { KE、上SHANG、 } \\
\text { 英YING、手 } \\
\text { SHOU、书SHU }\end{array}$ & $\begin{array}{l}\text { 爱: 爱人AIren(spouse)2 爱情AIqing(love)20 } \\
\text { 北 : 北京BEIjing(Beijing)13 北京烤鸭BEIjingkaoya(Beijing roast duck)11 } \\
\text { 车 : 车站CHEzhan(station)8 火车huoCHE(train)17 } \\
\text { 出 : 出CHU(out)15 出差CHUchai(business trip)18 } \\
\text { 打 : 打DA(hit,play)10 打工DAgong(work)12 打算DAsuan(plan)9 } \\
\text { 大 :大DA(general, major; adult; big)6 大概DAgai(roughly)15 大家DAjia(everyone)16 } \\
\text { 大学DAxue(university)13 大学生DAxuesheng(college student)5 } \\
\text { 电 : 电DIAN(electricity)18 电车DIANche(tram)8 电话DIANhua(telephone)12 电脑 } \\
\text { DIANnao(computer)7 电视DIANshi(television)8 电影DIANying(movie)6 电子词典 } \\
\text { DIANzicidian(electrical dictionary)7 } \\
\text { 多 :多DUO(many)6 多长时间DUOchangshijian(how long)14 多大DUOda(how old)7 } \\
\text { 多少DUOshao(how many)8 多高DUOgao(how tall)7 多少钱DUOshaoqian(how } \\
\text { much)11 } \\
\text { 法 : 法国FAguo(France)6 法文FAwen(French)10 } \\
\text { 可 : 可KE(but)18 可是KEshi(but)20 可惜KExi(unfortunately)10 可以KEyi(ok, may)10 } \\
\text { 上 : 上SHANG(up)8 上车SHANGche(get in the car)12 上课SHANGke(having class)9 } \\
\text { 上学SHANGxue(go to school)10 } \\
\text { 英 : 英国YINGguo(UK)6 英文YINGwen(English)10 英语YINGyu(English)5 } \\
\text { 手 : 手机SHOUji(mobile phone)11 手表SHOUbiao(watch)17 } \\
\text { 书 : 书SHU(book)8 书包SHUbao(bag)16 }\end{array}$ \\
\hline
\end{tabular}


(Table 2 continued)

\begin{tabular}{|c|c|c|c|}
\hline No. & extbook & Iorpheme & Occurrence in which lesson \\
\hline 7 & $\begin{array}{l}\text { Instantly use } \\
\text { Chinese }\end{array}$ & $\begin{array}{l}\text { 保BAO、病BING、 } \\
\text { 打DA、短DUAN、 } \\
\text { 感GAN、高GAO、 } \\
\text { 好HAO、网 } \\
\text { WANG、晕YUN、 } \\
\text { 自ZI }\end{array}$ & $\begin{array}{l}\text { 保: 保持BAOchi(maintain)15 保密BAOmi(maintain secrecy )5 保佑BAOyou(bless)8 } \\
\text { 病 : 病BING(sick)3 病人BINGren(patient)14 } \\
\text { 打 : 打DA(hit; play)11 打扮DAban(dress up)15 打搅DAjiao(disturb)1 打伞 } \\
\text { DAsan(hold up an umbrella)1 打扫DAsao(clean up)11 } \\
\text { 短 : 短期DUANqi(short time)4 短信DUANxin(short message)12 } \\
\text { 感 : 感动GANdong(moving)11 感情GANqing(sentiment)8 } \\
\text { 高 : 高兴GAOxing(happy)3 高原GAOyuan(plateau)8 高中GAOzhong(high school)4 } \\
\text { 好 : 好好儿HAOHAOr(good,well)15 好事多磨HAOshiduomo(The road to happiness } \\
\text { is filled with setbacks.)10 好运HAOyun(good luck)1 } \\
\text { 网 : 网WANG(internet)1 网上WANGshang(online)1 网上聊天室 } \\
\text { WANGshangliaotianshi(online chat room)8 } \\
\text { 晕 : 晕YUN(faint)9 晕倒YUNdao(pass out)13 } \\
\text { 自 : 自负ZIfu(conceit)8 自己ZIji(oneself)3 自我ZIji(ego)2 } \\
\text { 专 : 专攻ZHUANgong(specialize in)2 专家ZHUANjia(expert)5 专业 } \\
\text { ZHUANye(major)2 }\end{array}$ \\
\hline 8 & \begin{tabular}{|l} 
Progress \\
Everyday
\end{tabular} & $\begin{array}{l}\text { 打DA、好HAO、 } \\
\text { 结JIE、提TI、总 } \\
\text { ZONG、走ZOU }\end{array}$ & $\begin{array}{l}\text { 打 :打电话DAdianhua(call someone)2 打搅DAjiao(interrupt)9 打开DAkai(open)8 打 } \\
\text { 篮球DAlanqiu(play basketball)4 打算DAsuan(plan)1 } \\
\text { 好:好好儿HAOHAOr(good, well)2 好几个HAOjige(several)1 好玩儿HAOwanr(have fun)6 } \\
\text { 结 : 结婚JIEhun(get married)9 结束JIEshu(end)8 } \\
\text { 提 : 提供TIgong(provide)10 提起TIqimention()9 提前TIqian(in advance)2 } \\
\text { 总: 总觉得ZONGjuede(always feel)6 总算ZONGsuan(finally)3 } \\
\text { 走 : 走ZOU(walk)2 走过来ZOUguolai(come over)1 走开了ZOUkaile(go away)8 走 } \\
\text { 廊ZOUlang(corridor)5 }\end{array}$ \\
\hline 9 & Happ & $\begin{array}{l}\text { 出CHU、春 } \\
\text { CHUN、电DIAN、 } \\
\text { 好HAO、请 } \\
\text { QING、上 } \\
\text { SHANG、问WEN }\end{array}$ & $\begin{array}{l}\text { 出 : 出来CHUlai(come out)13 出去CHUqu(go out)5 } \\
\text { 春 : 春假CHUNjia(spring vacation)15 春节CHUNjie(spring festival)13 } \\
\text { 电 : 电车DIANche(tram)8 电脑DIANnao(computer)4 电梯DIANti(elevator)13 电影 } \\
\text { DIANying(movie)5 电子DIANzi(electrical)3 } \\
\text { 好 : 好HAO(good,well)1 好吃HAOchi(delicious)8 好看HAOkan(good-looking)10 } \\
\text { 请 : 请QING(please)7 请问QINGwen(excuse me)4 } \\
\text { 上 : 上课SHANGke(having class)7 上网SHANGwang()9 } \\
\text { 问 : 问WEN(ask)6 问题WENti(question)14 }\end{array}$ \\
\hline 10 & $\begin{array}{l}\text { Approach to } \\
\text { Chinese }\end{array}$ & $\begin{array}{l}\text { 别BIE、打DA、发 } \\
\text { FA、干GAN、请 } \\
\text { QING、确QUE、 } \\
\text { 认REN、上 } \\
\text { SHANG、同 } \\
\text { TONG、想 } \\
\text { XIANG、心XIN、 } \\
\text { 正ZHENG、自ZI、 } \\
\text { 做ZUO }\end{array}$ & $\begin{array}{l}\text { 别 : 别的BIEde(other)8 别人BIEren(other people)11 } \\
\text { 打 : 打猎DAlie(hunt)9 打麻将DAmajiag()4 打伞DAsan(hold up an umbrella)9 打折 } \\
\text { DAzhe(discount)4 } \\
\text { 发 : 发脾气FApiqi(lose temper)5 发现FAxian(discover)6 } \\
\text { 干 : 干脆GANcui(simply)5 干净GANjing(clean)10 } \\
\text { 请 : 请QING(please)8 请问QINGwen(excuse me)2 } \\
\text { 确 : 确认QUEren(confirm)7 确实QUEshi(actually)6 } \\
\text { 认 : 认生RENsheng(bashful)3 认识RENshi(know)10 认为RENwei(think,believe)8 } \\
\text { 上 : 上班SHANGban(working)7 上课SHANGke(having class)2 上瘾SHANGyin(beaddicted to)11 } \\
\text { 同 : 同班同学TONGbanTONGxu(classmate)e8 同窗会TONGchuanghui(classmate } \\
\text { gathering)8 同事TONGshi(colleague)12 } \\
\text { 想 : 想起XIANGqi()11 想像XIANGxiang(imagine)5 } \\
\text { 心 : 心情XINqing(mood)9 心事XINshi(have sth on one’s mind)5 } \\
\text { 正 : 正好ZHENGhao(just right)12 正在ZHENGzai(being)4 } \\
\text { 自 : 自家人ZIjiaren(one of us)11 自私ZIsi(slefish)5 自习ZIxi(self-study)4 } \\
\text { 做 : 做衣服ZUOyifu(make clothes)4 做卫生ZUOweisheng(clean up)6 }\end{array}$ \\
\hline
\end{tabular}


(Table 2 continued)

\begin{tabular}{|c|c|c|c|}
\hline No. & Textbook & Morpheme & Occurrence in which lesson \\
\hline 11 & Challenge Chinese & \begin{tabular}{|l} 
班BAN、报BAO、杯BEI、 \\
比BI、大DA、电DIAN、发 \\
FA、公GONG、好HAO、 \\
黑HEI、红HONG、滑HUA、 \\
鸡JI、教JIAO、进JIN、开 \\
KAI、前QIAN、上SHANG、 \\
手SHOU、书SHU、跳 \\
TIAO、吸XI、小XIAO
\end{tabular} & 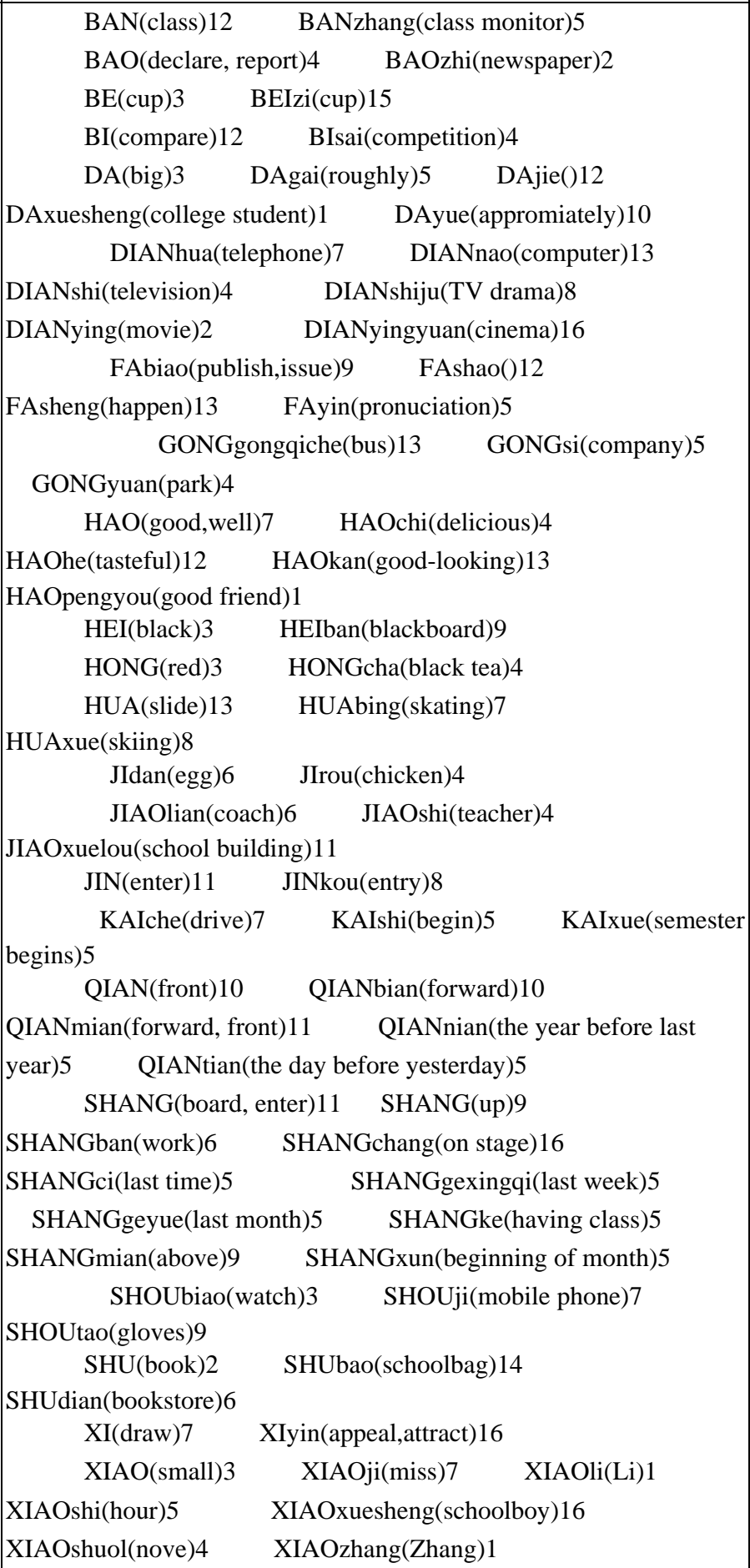 \\
\hline 12 & Listening Chinese & 男NAN、展ZHAN & $\begin{array}{l}\text { 男 : 男孩儿NANhair(boy)3 男朋友NANpengyou(boyfriend)5 } \\
\text { 展 : 展览ZHANlan(exhibition)7 展示ZHANshi(display)8 }\end{array}$ \\
\hline
\end{tabular}


(Table 2 continued)

\begin{tabular}{|c|c|c|c|}
\hline No. & Textbook & Morpheme & Occurrence in which lesson \\
\hline 13 & $\begin{array}{l}\text { Question and } \\
\text { Answer for Chinese }\end{array}$ & $\begin{array}{l}\text { fJDA、电DIAN、喝HE、 } \\
\text { 黑HEI、红HONG、几JI、 } \\
\text { 米MI、骑QI、上SHANG、 } \\
\text { 外WAI、小XIAO、有YOU }\end{array}$ & $\begin{array}{l}\text { 打 : 打电话DAdianhua(call someone)11 打工DAgong(work)12 } \\
\text { 电 : 电脑DIANnao(computer)8 电影DIANying(movie)11 电子词典 } \\
\text { DIANzicidian(electrical dictionary)10 } \\
\text { 喝 : 喝HE(drink)13 喝酒HEjiu(drink wine)8 喝啤酒HEpijiu(drink } \\
\text { beer)11 } \\
\text { 黑 : 黑HEI(black)5 黑板上HEIbanshang(on the blackbord)8 } \\
\text { 红 : 红HONG (red)5 红茶HONGcha(black tea)13 } \\
\text { 几 : 几JI(how many)4 几点JIdian(what time)12 几号JIhao(what } \\
\text { day;which number)7 } \\
\text { 米 : 米MI(rice)9 米饭MIfan(rice)13 } \\
\text { 骑 : 骑车QIche(ride a bicycle)12 骑马QIma(ride a horse)9 } \\
\text { 上 : 上SHANG(last)11 上个星期SHANGgexingqi(last week)7 上课 } \\
\text { SHANGke(having class)12 上学SHANGxue(go to school)2 } \\
\text { 外 : 外WAI(outside) 外边WAIbian 外面WAImian 外头 } \\
\text { WAItou(outside)11 外孙WAIsun(grandson) 外孙女 } \\
\text { WAIsunnv(granddaguther) 外祖父WAIzufu(grandfather) 外祖母 } \\
\text { WAIzumu(grandmother)4 } \\
\text { 小 : 小XIAO(small)9 小猫XIAOmao(kitty)11 小心XIAOxin(be } \\
\text { careful)8 } \\
\text { 有 : 有YOU(have)3 有道理YOUdaoli(reasonable)9 有机会 } \\
\text { YOUjihui(have an opportunity)13 有事YOUshi(have something)6 }\end{array}$ \\
\hline 14 & $\begin{array}{l}\text { Chinese Daily } \\
\text { Reading and } \\
\text { Dialogues }\end{array}$ & $\begin{array}{l}\text { 包BAO、成CHENG、发FA、 } \\
\text { 高GAO、交JIAO、开KAI、 } \\
\text { 亲QIN、同TONG、想 } \\
\text { XIANG、游YOU、约YUE、 } \\
\text { 之ZHI }\end{array}$ & $\begin{array}{l}\text { 包 : 包BAO(bun)7 包子BAOzi(stuffed steamed bun)9 } \\
\text { 成 : 成功CHENGgong(success)8 成绩CHENGji(testing results)1 成 } \\
\text { 语CHENGyu(idioms)6 } \\
\text { 发 : 发霉FAmei(get mouldy)4 发生FAsheng(happen)1 发现 } \\
\text { FAxian(find out)3 发展FAzhan(develope)1 } \\
\text { 高 : 高不可攀GAObukepan(beyond one's reach)10 高大 } \\
\text { GAOda(tall)10 高空GAOkong(high altitude)10 高兴 } \\
\text { GAOxing(happy)5 } \\
\text { 交 : 交JIAO(exchange)6 交流JIAOliu(communicate)1 交往 } \\
\text { JIAOwang(communicate)7 } \\
\text { 开 : 开车KAIche(drive)10 开口KAIkou(start to talk)1 开始 } \\
\text { KAIshi(begin)1 开学KAIxue(semester begins)7 } \\
\text { 亲 : 亲身QINshen(first hand)6 亲手QINshou(by hand)5 } \\
\text { 同 : 同时TONGshi(at the same time)5 同学TONGxue(classmate)1 } \\
\text { 想 : 想XIANG(think)5 想像XIANGxiang(imagine)10 } \\
\text { 游 : 游YOU(travel)10 游记YOUji(travel notes)10 游览YOUlan(go } \\
\text { sight-seeing)6 } \\
\text { 约 : 约YUE(appointment)10 约好YUEhao(make an appointment)8 } \\
\text { 之 : 之后ZHIhou(afterward)6 之外ZHIwai(in addition)2 }\end{array}$ \\
\hline
\end{tabular}

Note. Numbers in the table represent the lesson. This table only lists some of the examples in textbooks.

As shown in Table 2, although many words with same morpheme exist in the vocabulary list, they are still in different lessons. For example, six words derive from the common morpheme "vehicle" (车) in Kumi Shanghai Trip. The semantic meanings are interrelated, but they did not occur at the same time. These words exsit in different parts of the textbook: “station” (车站) is in Lesson 5, “tickets” (车票) and “train” (火车) in Lesson 10, “inside the car” (车里) in Lesson 13, “tram” (电车) in Lesson 14, and “train station” (火车站) in 
Lesson 15. Words appear in same occasions, same topics but in different places, which makes memorizing vocabulary more difficult. It is easier to memorize "-vehicle" (-车) or "vehicle-" (车-) and so many words among all the words with core morpheme "vehicle". The authors believe that words with core morpheme "vehicle" are semantically interrelated, belonging to the same semantic group. Learners can study the core word "vehicle" first, and then move to the words with same morpheme "vehicle", which is linked to words like "station, in the car, ticket, tram, train, railway station". In such an effective way, learners can not only remember these words with less effort, but also the words with disyllables related "vehicle" through association. Unfortunately, the monosyllables excluded from the word list.

Meanwhile, the authors note that the majority of words "male..." and "female..." are composed of morpheme “male" (男) or “female” (女) do not exist in the same lesson, and only “male..." and "female..." exist in some textbooks. For instance, “girlfriend” (女朋友) is present in Lesson 3, but “boyfriend” (男朋友) appears until Lesson 10 in Chinese Time and Campus Life in Chinese, while these two words list in the same lesson in Happy Chinese. The pair words "male..." and "female..." are semantically intertwined both in Japanese and Chinese, thus it is easier for learners if they appear synchronically.

\section{The Necessity of Using Morpheme "Radial Network” in Vocabulary Teaching}

\section{The Necessity of Learning Morphemes in Beginning Stage}

For Chinese learners with Japanese mother tongue, many learners tend to rely on Japanese to create a Chinese vocabulary system in the early learning stage. As two nations share Chinese characters, and Chinese characters are regarded as a significant factor. Because Chinese characters are important elements for Japanese word formation, thus Chinese morpheme teaching could be an effective method for Japanese learners.

In The Study on Vocabulary and Vocabulary Teaching in Teaching Chinese for Foreigners, SUN De-jin (2006) extracted 3,000 most frequently occurring words from Modern Chinese Frequency Dictionary (1986) published by the Beijing Language Institute. He also examined frequency occurrence for monosyllables and disyllables. Judging from 3,000 most frequently occurring words, the number of monosyllables is as much as three times of disyllables. Overlapping words with the morpheme's semantic meaning and the semantic meaning itself are at high proportion in high frequently occurring words, which indicates of the existence of abundant monosyllables. Words in ancient Chinese vocabulary become unable to use individually due to the evolvement of disyllables, which have been seen as "root" in modern Chinese. Those morphemes, considered as the most active elements, are frequently used in the word formation of Chinese.

The study result by SUN De-jin (2006) reveals that most of basic vocabularies in Chinese are constituted by adding of morphemes' semantic forms. Therefore, focusing on morpheme teaching and vocabulary formation teaching can be conducive to vocabulary learning for Chinese learners. Chinese vocabulary contains the feature of grammatical structure leading to be beneficial to grammar study. However, the purpose of morpheme teaching is not only writing and understanding morpheme itself, but also the mastery of the word-formation rules to help memorize new words.

\section{Psychological Linguistic Theory}

GUI Shi-chun (1991) pointed out that a prerequisite of study is establishing association between new information and known information. But known information stores in long-term memory in a proposition network form. The activation of knowledge in long-term memory proceeds along the route of network. In addition, because each concept has its own proposition network, the activation can spread its surrounding 
concepts (so called "spread of activation"), far more than "activation" concept itself. Through spread of activation, new proposition promotes the extraction of known information and creation of another new proposition through addition, but all the new propositions store surrounding activated known information. When storing a new proposition and known information in proposition network, this is acquisition of new knowledge.

In other words, establishing new concept is based on the old concept. Then adding a variety of materials, concept is fastened in new fields by associative network. For example, if you want to build the concept "pipa" (a traditional Chinese musical instrument), you need to understand the first broad concept "music", then divide it into "Chinese folk music" and "western music". Thirdly, establishing the connection between "pipa" and "Chinese folk music", finally you can know that "pipa" is a "musical instrument" of "Chinese folk music". This exemplifies the fixation process of new concept "pipa" by appliance of associative network from "music" to "pipa”.

Learning vocabulary should always memorize known words to form network. Attempting to fasten new words should understand new words based on core words or morphemes, then combine them with new words with same morphemes to establish a new network. Take "electricity” as an example (see Figure 1).

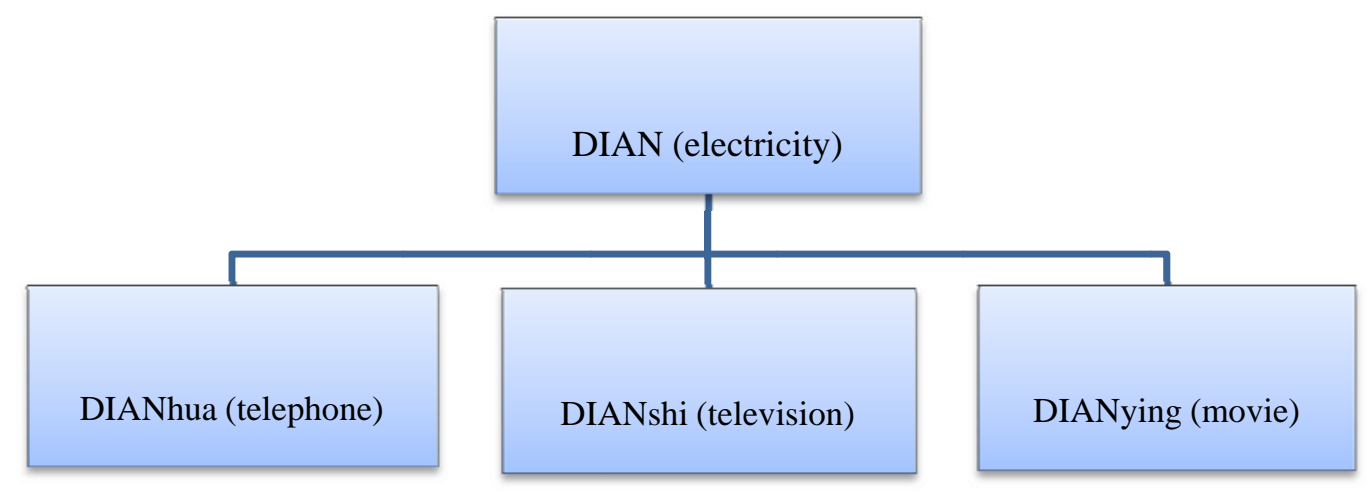

Figure 1. Radial network of morpheme "DIAN (electricity)".

As shown in Figure 1, this can allow learners to study "electricity" as preparation vocabulary, then combine new words: "telephone”, "television”, and "movie” through semantic morphemes. This paper defines "electricity" as core morpheme, and the whole network as "radial network".

\section{Formation of Vocabulary "Radial Network"}

With morpheme of word-formation as the basic unit, using the lexical-semantic network, new words can be reproduced with same morpheme. If it is a function word, learners can expand from a function word to related grammar, showing the close relation between vocabulary and syntax. Taking a subject as an example, radial network is a substance with same elements which spreads from a core in a radial way, forming a network. The relation between disyllables and morphemes can use it as a metaphor.

Generally speaking, taking the words with semantic morpheme as core words, those words convene with similar words composed of restrictive elements of extent, nature, etc., resulting in similar semantic "network". Core words are consisted of words with strong word-formation and words with same morpheme (see Figure 2). For instance, according to Modern Chinese Dictionary, the core morpheme "open" in "open the door", "unlock", and "opening" means "make closed things no longer closed". But the core morpheme "open" in 
“semester begins", "lecture begins”, and "war begins” means "begin”. The core morpheme "open” in "begin”, "shoot", "drive" means "starts the engine or control". In other words, "open" has three different semantic meanings. In addition, “open” in "make it through”, "hold”, "pay”, "serve the (table)” can also be divided into another meaning collections. As mentioned above, the core morpheme "open" can assemble with disyllabic words with same morphemes forming radial network (see Figure 2).

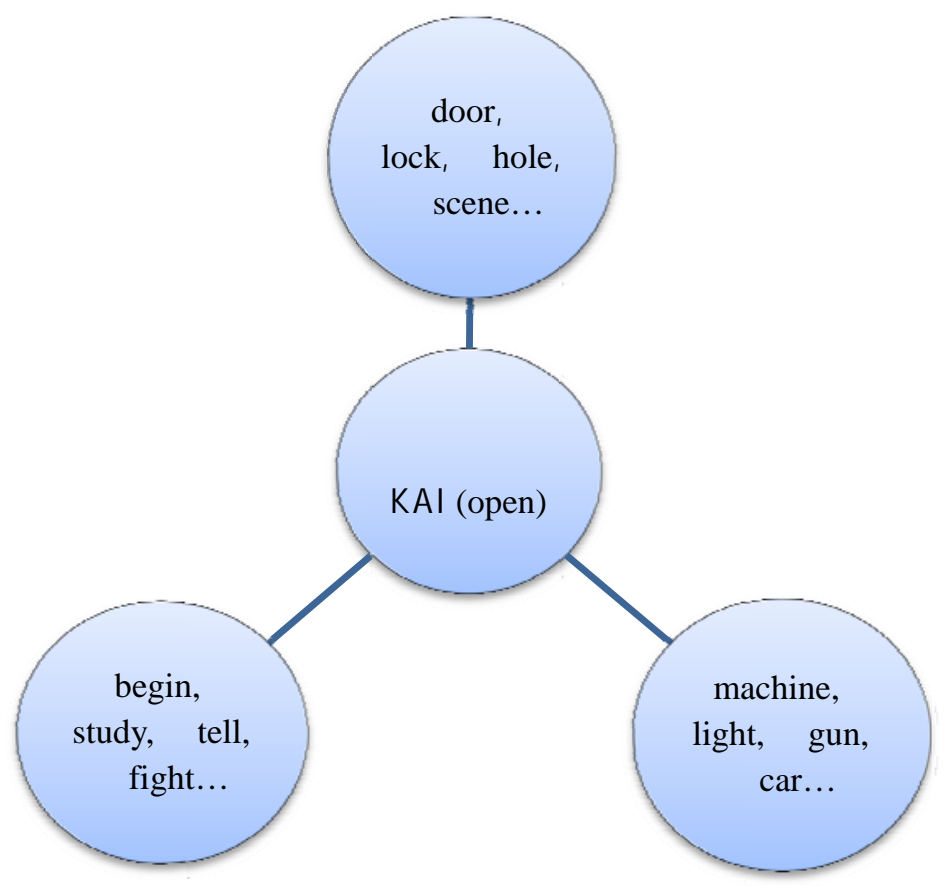

Figure 2. Radial network of morpheme "KAI (open)".

\section{Conclusion}

This paper examines new word arrangement in elementary Chinese textbooks published from 2006 to 2008, and also specifically analyzes the occurrence order of some words with same morphemes. The author believes that words with same morphemes diffuse in different lessons rather than listing them synchronically. Furthermore, words with same morphemes in Chinese are relatively easier to memorize. Thus, morpheme teaching is an effective method because Japanese also use Chinese characters.

Meanwhile, the author proposes that using common morphemes in a "radial network" in vocabulary teaching methods can allow learners to learn them in advance by examining internal structure of compound words. In this way, it can not only promote learners to remember words in textbooks, but also to infer the meaning of the word through associating from known core morphemes.

\section{References}

Beijing Language Institution Teaching. (1986). Modern Chinese frequency dictionary. Beijing: Beijing Language College Press. Editing Room in Linguistic Institute of Chinese Academy of Social Sciences. (2012). Modern Chinese dictionary (6th ed.). Beijing: Commercial Press.

GUI, S. C. (1991). Experimental psychologist outline. Changsha: Hunan Education Press.

HE, B. Y., ZHANG, H., \& CHEN, S. Y. (1983). Experimental psychology. Beijing: Beijing University Press.

SUN, D. J. (2006). The study on vocabulary and vocabulary teaching in teaching Chinese for foreigners. Beijing: Commercial Press. 
XU, C. H. (2002). Processing of Chinese monosyllables in psychological dictionary. International symposium on Chinese language and cognition. Beijing: Beijing language and Culture University Press.

ZHANG, H. S. (2005). Review of vocabulary teaching in Chinese as second language. Applied Linguistics, (9), 6.

ZHANG, W. X. (2000). The sixth international seminar on teaching Chinese paper review. World Chinese Teaching, (1), 3.

ZHOU, G. G. (2004). Modern Chinese textology introduction. Guangzhou: Guangdong Higher Education Press. 